\title{
Skill Development in Lockdown through Self-learning
}

\author{
Antima Sharma ${ }^{1}$ and Rinku Raghuvanshi ${ }^{2}$ \\ ${ }^{1}$ Research Scholar and ${ }^{2}$ Associate Professor, \\ Management, Bhartiya Skill Development University, Jaipur, Rajasthan, India.
}

CITATION: Sharma, Antima and Raghuvanshi, Rinku (2020), "Skill Development in Lockdown through Self-learning", MERC Global's International Journal of Management, Vol. 8, Issue 3, pp. 6974.

ARTICLE HISTORY: Submitted: March 12, 2020, Revision received: April 23, 2020, Accepted: May 12, 2020

ARTICLE TYPE: Review paper

\begin{abstract}
The world is ever-changing and too unpredictable. The situations, techniques, methods, challenges and criteria are changing so fast that it is tough to cope with all these with our traditional approaches and learning. To achieve our aspirations, desires and to stay updated in changing world self-learning is the tool and it is learning about today's world. If we see right now situation where the whole world is suffering from Coronavirus disease 2019 (COVID -19) is a communicable disease first found in Dec 2019 in Wuhan, the capital of China. The World Health Organisation (WHO) declared the coronavirus is a Public Health Emergency. Countries' Government has taken social distancing as a measure preventive tool against the Corona Virus and made the complete lockdown. All the activities have got to stop except emergency, and people get locked in their houses. The measure issue is how to utilise this time in a constructive way and keep ourselves ready for the future. So, this article focuses on the self-development of people with self-learning practices in the lockdown period. The article will put highlight what can be the self-learning tools through which we can enhance our different skills.
\end{abstract}

KEYWORDS: Self-learning, COVID-19, WHO, Self-development tools, Lockdown.

\section{REFERENCES}

1. Eliason, Nat (2017), Self-Education: Teach yourself anything with the Sandbox Method, available at: https://www.nateliason.com/blog/self-education.

2. Field, J. (2000), Lifelong learning and the new educational order, Trentham Books, Ltd., Westview House, 734 London Road, Stoke on Trent, ST4 5NP, United Kingdom.

3. Girija, V. (2020), "A study on the interest of students using social media in learning during lockdown period (Covid-19)", Purakala, Vol. 31, Issue 4, pp. 2452-2457.

4. Khanna, R. C.; Cicinelli, M. V.; Gilbert, S. S.; Honavar, S. G. and Murthy, G. S. (2020), "COVID-19 pandemic: Lessons learned and future directions", Indian Journal of Ophthalmology, Vol. 68, Issue 5, pp. 703.

5. Vermunt, J. D. and Van Rijswijk, F. A. (1988), "Analysis and development of students' skill in selfregulated learning", Higher Education, Vol. 17, Issue 6, pp. 647-682.

6. White, E. and Jarvis, J. (2019), Self-study: a developing research approach for professional learning, University of Hertfordshire.

7. World Health Organisation (2020), Coronavirus disease 2019 (COVID-19): Situation report, 72.

8. Zhu, M. and Bonk, C. J. (2019), "Designing MOOCs to facilitate participant self-directed learning: An analysis of instructor perspectives and practices", International Journal of Self-Directed Learning, Vol. 16, Issue 2, pp. 39-60.

9. Zimmerman, B. J. and Schunk, D. H. (2011), Handbook of self-regulation of learning and performance, Routledge/Taylor \& Francis Group. 